\title{
Performa Indonesia pada Riset Konsorsium Energi: Asesmen Bibliometrik Jurnal Ilmiah Internasional
}

\author{
Himawanto* \\ Email: himawanto@lemigas.esdm.go.id; himawanto1980@gmail.com
}

\begin{abstract}
Research activities are defence actions of researchers in all countries including Indonesia to overcome the threat of energy crisis. Such activities require partnership in order to produce credible scientific works on energy that can be disseminated in reputable scientific publications. ScienceDirect is a prestigious publication worth exploring in order to measure the Indonesian researchers collaboration in the international arena. Bibliometric assessments are used to know evolution of research collaboration, construction research, research leadership, and involvement of colleagues. Research collaboration led by Indonesia for over a decade resulted in 207 articles with rapid growth trends. Research achieved by the emergence of 802 researchers and 363 affiliates, published over 14 reputable journals with ratio of 3.87 researchers. While the ratio of institution, country and region reached index more than one. Only in the period of 2010-2011 architecture of absolute research was achieved through international collaboration. For a decade the academic research construction had proved productive in article publishing. Meanwhile the scientific collaboration led by 68 local institutions set aside $28.02 \%$ of global-scale research. Domestic institutions residing in 18 provinces and Aceh were the zone with fantastic collaboration index. Indonesia also built coalition with 21 countries and Japan was the most active in supporting national research. Partner countries delegated as many as 50 research institutions to collaborate.
\end{abstract}

Keywords: International scientific journals, International collaboration, Bibliometrics, Energy, Collaboration index

*Pustakawan Puslitbangtek Migas "LEMIGAS”, Kementerian ESDM

\section{A. PENDAHULUAN}

Penelitian energi terlahir sebagai upaya perlawanan terhadap ancaman krisis bahan bakar minyak yang terus menyusut. Bukan hanya di negara maju sekalipun, riset energi juga dianggap sebagai model defensi bagi negara berkembang seperti Indonesia. Terlebih level ketahanan energi nasional bersumber minyak sudah masuk pada kelompok rentan (Nugroho, 2015:80). Namun guna mewujudkan suatu riset bukanlah perkara yang simpel bagi kalangan peneliti. Aksi riset energi tentu tidak lepas dari pengaruh anggaran. Hingga kini faktor pendanaan bahkan sering dikaitkan dengan kesuksesan riset itu sendiri. Rendahnya pembiayaan riset energi bisa jadi akan diterjemahkan sebagai perjuangan yang minim pula. Atau bisa dipersepsikan juga periset telah dihadapkan dengan bahaya lain diluar persoalan sebenarnya. Namun besar kecilnya investasi riset energi, kenyataanya selalu berhasil mengintimidasi aktivitas peneliti secara kontinu. Suksesnya intervensi pendanaan terhadap kinerja peneliti tentu terlihat dari total karya ilmiah yang terbit secara konsisten dan berkala. Begitu juga terindikasi dari seberapa banyak termuat dalam jurnal internasional apabila Indonesia ingin mengukur kemajuan pengetahuan dan teknologinya (Surjandari et al, 2015:650). Semakin banyak tulisan saintifik milik Indonesia terpublikasi pada jurnal prestise, menandakan agresifnya peneliti nasional berperang mengatasi persoalan energi.

Selain berpola mandiri, suatu karya ilmiah biasanya juga diperjuangkan secara kolaborasi. Taktik kolaborasi merupakan modus operandi yang dominan diadopsi ilmuwan untuk memecahkan persoalan berkategori rumit. Fakta bahwa kiat kolaborasi selalu menaklukan suatu perolehan karya riset individu memang 
tidak terbantahkan lagi. Beberapa studi publikasi berasas data Scopus atau Thomson Reuters, terlihat bahwa derajat kolaborasi pada terbitan IJC 2007-2011 mencapai 0.82 (Maryono et al, 2012:20; 2012:128). Lalu Dutt et al $(2013: 123 ; 2014: 68)$ tentang tema tenaga surya sebesar $96.10 \%$ (1945/2024 publikasi). Kemudian Dutt et al (2015:160) mendeklarasi kembali mengenai bidang yang sama dengan publikasi kooperasi senilai $94.53 \%$ $(10.308 / 10.905)$. Begitu juga riset energi dan bahan bakar di Cina dengan tulisan ilmiah kolaborasi 76.7\% (Chen et al, 2016:971). Demikian halnya di Rusia tentang riset nano karbonnya mencapai $93.7 \%$ (Terekhov, 2015:13). Bagi Indonesia, kooperasi ilmiah bukanlah hal baru disetiap aksinya. Indonesia pernah menuntaskan seluruh misi riset kolaborasi karbondioksidanya hingga terpublikasi pada terbitan berlevel Scopus (Karimi et al, 2015:367). Jika dihubungkan dengan persoalan dana, siasat konsorsium ilmiah tentunya tidak akan membebankan Indonesia secara sepihak.

Tidak kalah pentingnya, sekutu konsorsium juga berperan dalam meledakan jumlah karya ilmiah. Pada kelompok negara G20, Indonesia terlibat aktif pada kolaborasi saintifik internasional (Mindeli et al, 2015:62). Bergabungnya Indonesia secara langsung akan menguntungkan posisinya sendiri maupun kolega sahabat dalam upaya merakit sebuah karya ilmiah. Selain itu, pola bilateral ataupun multilateral pada kelompok tersebut berpeluang menghasilkan sebuah produk saintifik bertaraf internasional. Amat disayangkan jika periset nasional kurang mampu mengoptimalkan koalisi yang sudah terjalin. Terlebih konsorsium universal demikian tidak sederajat dengan sarana publikasi yang mewadahinya. Padahal wadah penerbitan ilmiah sangat vital kedudukannya, utamanya yang berprestise global. Science Direct salah satunya, untuk dipertimbangkan bagi peneliti Indonesia jika berkeinginan memajang karya risetnya, termasuk yang berhaluan pada topik energi. Apalagi mayoritas publikasi Science Direct seperti terbitan berkalanya sudah terindeks di Scopus dan Thomson Reuters. Jika periset nasional ingin memenangkan reputasi secara cepat, maka karya ilmiahnya perlu menginvasi jurnal Science Direct. Oleh sebab itu Science Direct dijadikan alasan pokok untuk mengenali pertalian ilmiah Indonesa yang berdampak bagi evolusi karya risetnya. Khususnya yang mengungkap isu energi yang selama ini menjadi basis keresahan seluruh negara termasuk Indonesia. Riset konsorsium bertajuk energi amatlah signifikan faedahnya jika berhasil mengundang kepedulian ilmuwan untuk terus mengembangkannya. Ilmuwan akan menyempurnakan sumber pengetahuan tema energi yang sudah terpublikasi lebih dahulu. Bagi Indonesia riset konsorsium ilmiah merupakan amunisi untuk mengatasi persoalan induk serta akan mengurangi beban sesama anggota mitra. Science Direct menjadi kendaraan publikasi sepadan dan menguntungkan bagi koordinator serta mitra koalisi. Kolaborasi periset nasional berpotensi menaikkan pamornya di komunitas global. Selain itu, Indonesia akan memperoleh pengakuan dan kepercayaan karena keaktifannya pada ajang riset energi berkelas. Jurnal ilmiah identik memiliki kebaruan karena bisa terpublikasi berkala dan teratur. Banyaknya karya ilmiah konsorsium termuat pada jurnal Science Direct, maka cepat pula bahaya krisis energi akan teratasi.

Untuk mengetahui seberapa kuat agresi riset konsorsium nasional ke jurnal ilmiah Science Direct bertajuk energi, digunakan asesmen bibliometrik. Sementara itu kajian bertujuan menjalankan operasi (1) pendeteksian pertumbuhan riset kolaborasi; (2) penelusuran konstruksi perserikatan penelitian; (3) penyelidikan daya kepemimpinan lembaga riset; dan (4) pencarian keterlibatan kolega peneliti. Kajian ini mencita-citakan aksi kekompakan ilmuwan dalam memerangi bencana krisis energi. Jika wujud kesetiakawanan tersebut mampu dikoordinasikan periset Indonesia secara kontinu, maka kapasitas karya riset energi berpotensi melonjak pesat. Termasuk mengangkat kejayaan Indonesia di festival pengetahuan bergengsi.

\section{B. TINJAUAN PUSTAKA}

Konsorsium atau dapat disebut juga kolaborasi, merupakan salah satu model ciri aktivitas dalam menciptakan produk pengetahuan. Kolaborasi sendiri dapat diartikan sebagai kerja sama antara lebih dari satu orang atau lebih dari satu lembaga dalam sebuah kegiatan, baik kegiatan penelitian maupun 
pendidikan. Jenis kolaborasi peneliti terbagi atas dosen-mahasiswa, antar teman sejawat, pengawas-asisten, peneliti-konsultan, berbagai lembaga riset, dan kolaborasi internasional (Subramanyam, 1983 dalam Tambunan, 2013:109). Disisi lain kajian mengenai konsorsium riset internasional enam belas proyek di LIPI berhasil terdeteksi desain kemitraan antara pemerintah, akademisi, dan bisnis (Fizzanty et al, 2013:106). Pola kemitraan juga turut mempengaruhi tingkat partisipasi periset, meskipun dengan rerata bervariasi. Semisal topik bahan bakar nabati oleh Yaoyang et al (2013:83) yaitu 3.5 peneliti (P), bidang tenaga surya oleh Du et al (2014:698) mencapai 3.45 P, dan tajuk mitigasi karbondioksida dari Wan et al (2012:88) sebesar 3.7 P. Begitu juga karya ilmiah yang difokuskan pada isu energi yakni $3.5 \mathrm{P}$ (Hou et al, 2015:544). Kelihatannya kolaborasi dilandasi oleh kerumitan masalah yang akan diatasi.

Kompleksnya perkara energi bahkan bisa memicu tumbuhnya aksi kerja sama yang bersifat luas. Misalnya kerja sama dengan negara lain atau beberapa teritorial yang memiliki keinginan sama. Kerja sama demikian bisa disebut juga kooperasi internasional. Indonesia pernah menorehkan catatan bahwa dilingkup negara Islam, seluruh publikasinya termasuk bertopik energi sejak tahun 20002011, mutlak diperoleh secara kolaborasi internasional (Sarwar et al, 2015:1072). Padahal Amerika Serikat sebagai negara terkuat penghasil artikel bertema bahan bakar nabati, kolaborasi internasionalnya $30.26 \%$ (Mao et al, 2015:279) dan 36.05\% (Mao et al, 2015:1825). Demikian juga menurut Casado et al (2014:742) mengenai publikasi tema tenaga surya yang mendapatkan kooperasi global negara Jerman (33.7\%) dan Spanyol (33.9\%). Meskipun belum sepadan kapabilitasnya, namun bukan hal simpel dalam mengetuai sebuah koalisi bertaraf global. Kompetensi periset Indonesia akan menjadi kunci penentu, atau mereka harus berhadapan dengan risiko soal rendahnya jumlah karya riset yang bisa diperoleh.

Taktik konsorsium penting diperkuat apabila peneliti berkeinginan meletuskan karya ilmiah lebih banyak. Periset perlu membagi porsi yang seimbang guna menyalurkan karya kolaborasinya. Sehingga bidikannya tidak selalu mengarah ke terbitan lokal saja, meskipun telah terakreditasi. Terbitan prestise seperti jurnal internasional milik Science Direct perlu dijadikan sasaran peneliti. Apalagi Science Direct memiliki daya pikat untuk dibaca dan berpeluang dimanfaatkan sebagai rujukan serta dikutip publikasi lain (Nusantari, 2014:93). Implementasi Science Direct pada pusat litbang pertanian bahkan cenderung lebih besar jika dipadankan jurnal online lainnya (Rufaidah et al, 2012:22). Termasuk di institusi LIPI, Science Direct dipakai untuk memenuhi kebutuhan peneliti dan sivitasnya (Rahayu, 2013:30). Terlebih sejak 2010-2012, LIPI paling banyak mengunduh jika dibandingkan 9 pengakses lain hingga 115.504 artikel (Nashihuddin et al, 2013:6). Dapat diartikan bahwa fenomena Science Direct sukses membius ilmuwan karena menyandang kesohoran yang terbilang eksklusif. Meskipun citra Science Direct turut dibangun dari terbitan karya riset mandiri bereputasi, namun karya kolaborasi nampak selalu dominan.

Tidak disangsikan bahwa publikasi Science Direct mengundang ketertarikan untuk dikaji. Seperti lazimnya sebuah publikasi, unsur bibliografi yang terkandung pada jurnal Science Direct juga memiliki kesamaan. Misalnya judul artikel, penulis, afiliasi, dan periode terbit. Dari dimensi teori perpustakaan dan informasi, unsur kepengarangan dapat ditelisik guna mengetahui cara pengerjaannya, yakni secara sendiri atau kolaborasi. Konsep bibliometrik sebagai cabang ilmu perpustakaan, banyak dimanfaatkan untuk menelisik literatur dengan kaidah matematika dan statistika. Sedangkan untuk mengetahui strata kolaborasi dan produktivitas periset, umumnya dianut bibliometrik berciri deskriptif (Pattah, 2013:48). Unsur afiliasi yang menempel pada pengarang bisa juga diekspansi menurut ciri geografisnya, semisal nama negara, regional, serta benuanya (Anyi et al, 2009:45). Untuk perluasan, ciri geografis terhadap unsur afiliasi yang berasal dari Indonesia berpeluang diuraikan menurut nama propinsi dan kepulauan. Dengan demikian unsur penulis dan afiliasi yang melekat pada sebuah karya saintifik Science Direct mempunyai prospek untuk dipelajari karakter kolaborasinya.

Sementara itu penentuan derajat dan indeks kolaborasi umumnya terfokus kepada tiga kelompok utama. Kelompok tersebut berbasis pada penulis, institusi dan negara. Beberapa studi bibliografi yang mengupas ketiganya bisa 
diketahui pada topik energi (Zhang et al 2016:304), bidang kebumian (Wang et al 2014:1658) atau tajuk kesehatan (Yu et al, 2013:632). Hal yang sama tercermin juga pada kajian bibliometrik Gazni et al (2012:326) dan Wang et al (2013:885). Berdasarkan sejumlah pembanding, tidak tertutup kemungkinan bahwa unsur geografis bisa diperluas zona kolaborasinya. Unsur geografis dimaksud yaitu identitas kewilayahan Indonesia seperti nama propinsi dan kepulauan. Tujuannya agar karya riset bidang energi milik Indonesia dapat diketahui juga tingkat atau rasio kooperasinya.

\section{METODE}

Untuk melancarkan kebutuhan kajian, ditempuh penggalian sumber data ke portal Science Direct (www.sciencedirect.com). Strategi penelusuran dimulai dengan membuka fasilitas advanced search pada basis data jurnal ilmiah. Selanjutnya digunakan kriteria "Indonesia in Affiliation" AND "Energy in Journal Name". Dipilihnya kriteria nama jurnal karena topik yang membahas energi biasanya diberi judul spesifik agar mudah dikenali dan dipahami pada saat pelacakan. Lalu area pencarian dipersempit dengan memilih kelompok artikel (article) kurun waktu 20062015. Menurut hasil pendeteksian telah ditemukan 322 artikel dan sejumlah $70.50 \%$ (227 artikel) diketahui berasal dari pengarang utama asal Indonesia. Dari kepemilikan nasional maka seluruh karya ilmiah akan dipisahkan berdasarkan formasi kepengarangannya. Sedangkan formasi untuk karya kooperasi berfungsi sebagai pemicu utama kajian.

Kesemua artikel yang telah berhasil dilacak, dilanjutkan dengan tindakan penyimpanan ke dalam Ms. Excel 2010. Sampai saat ini piranti lunak tersebut masih terus dijadikan andalan dibeberapa kajian bibliometrik terbaru. Diantaranya tajuk kesehatan (Wei et al, 2016:977; Hoppen et al, 2016:3), bidang energi (Jiang et al, 2016:228; Chen et al, 2015:13), dan topik pertanian (Guo et al, 2016: 329). Elemen yang prospek direkam meliputi judul artikel, penulis dan afiliasinya, nama jurnal, serta periode terbit. Penambahan kolom akan dipersiapkan guna memberi ruang terhadap perluasan elemen afiliasi penulis. Khususnya yang menyangkut aspek geografis menurut titik lokasi institusi peneliti berada.
Sedangkan semua elemen data yang direkam aplikasi Ms. Excel diletakan pada satu lembar kerja (sheet) mandiri.

Selanjutnya guna menetapkan kinerja konsorsium, digunakan kaidah peneliti utama sebagai tolok ukurnya. Kaidah tersebut juga berlaku bagi penentuan prestasi lembaganya. Diikuti juga dengan unjuk kerja geografisnya dengan acuan lokasi institusi ilmuwan berada. Artikel Science Direct membubuhkan ciri aksara atau angka bagi setiap penulisnya. Apabila dijumpai penulis beraliansi ganda atau lebih dari satu, maka rujukannya yaitu ciri aksara atau angka pertama. Informasi terkait penulis juga bermanfaat untuk mengetahui rasio kepengarangannya. Sehingga formula yang berkaitan dengan hal tersebut akan diaplikasikan yaitu indeks kolaborasi atau disebut juga collaboration index (CI). Formula CI menurut (Rousseau, 2011:172; Liao et al, 2012:28):

$$
C I=\frac{\sum_{j=1}^{A} j f_{j}}{N}
$$

$$
\begin{aligned}
C I= & \text { Indeks kolaborasi } \\
f_{j}= & \text { Jumlah produk riset dengan } j \text { peneliti } \\
N= & \text { Total produk riset (artikel) yang } \\
& \text { dihasilkan }
\end{aligned}
$$

Rumus CI diterjemahkan sebagai rasio jumlah peneliti terhadap karya riset yang diraih. Demikian juga diterapkan guna menentukan rasio menurut afiliasi dan geografisnya. Sedangkan definisi yang terkait dengan kolaborasi pada kajian ini diantaranya: (1) artikel afiliasi tunggal jika semua perisetnya berasal dari institusi singular, (2) artikel satu negara apabila seluruh afiliasi penelitinya bermukim di teritorial yang sama, (3) artikel mono regional didasarkan pada negara asal periset yang terhimpun di kawasan sejenis, dan (4) kooperasi internasional yaitu produk ilmiah yang melibatkan ilmuwan dari negara lain. Melalui indeks kolaborasi, dapat diprediksi tingkat kerumitan masalah energi yang diatasi Indonesia.

Dalam hal menjamin keakurasian elemen institusi periset, maka ditempuh langkah validasi. Aksi tersebut bertujuan mencari kesamaan identitas untuk mengantisipasi kurang konsistennya penyebutan lembaga penulis. Mengingat adakalanya pencantuman 
institusi pengarang dijumpai dengan penamaan kurang seragam. Terkait institusi yang berasal dari perguruan tinggi atau universitas, serta pemerintah di dalam negeri, maka menggunakan identitas orisinal Indonesia. Sedangkan guna menjawab keraguan tentang organisasi yang tidak sama, maka ditempuh kegiatan pendalaman dengan membuka tautan website ditempat pengarang bernaung. Kegiatan investigasi akan diarahkan untuk mencari keterangan yang sahih demi kepentingan observasi di lembar kerja.

Kendali bibliometrik, maka operasi difokuskan terhadap karya riset kolaborasi Indonesia bertajuk energi di Science Direct. Tahapan kegiatannya adalah: (1) mengusut pertumbuhan dan fasilitas publikasinya, (2) menyelidiki arsitektur kelompok kerja riset, (3) menganalisis prestasi kepemimpinan, dan (4) menginvestigasi mitra kooperasi periset. Kegiatan analisis mentargetkan format tabulasi untuk tujuan observasi dan penyusunan peringkat. Wujud tabulasi akan disederhanakan dan dipindahkan ke dalam rancangan ideal bentuk tabel atau ilustrasi. Sehingga mudah diinterpretasi secara deskriptif.

\section{HASIL DAN PEMBAHASAN}

\section{a. Evolusi Konsorsium IImiah}

Selama kurun waktu 2006-2015, terlihat pada gambar 1 menunjukkan riset konsorsium bidang energi yang diketuai Indonesia sebesar 207 artikel. Hasil riset kooperasi tersebut bernilai 91.19\% menurut 227 artikel yang telah dipublikasi selama satu dasawarsa di Science Direct. Di masa itu juga, riset konsorsium Indonesia telah didukung oleh frekuensi kehadiran 802 ilmuwan dan 363 institusi. Pertumbuhan riset kolaborasi mulai beranjak naik sejak tahun 2012 dan terus melonjak drastis hingga periode 2015. Demikian juga diikuti dengan keaktifan peneliti beserta institusinya yang terbilang agresif. Nampaknya riset energi memiliki daya magnet untuk diproduksi Indonesia secara bersama. Sedangkan kiat mandiri untuk menciptakan sebuah karya riset kurang diminati oleh peneliti nasional. Para peneliti agaknya juga menyadari bahwa dengan berkolaborasi maka gagasan inovatif yang dapat disumbangkan akan lebih banyak. Apalagi gagasan tersebut secara nyata dapat tersalurkan pada publikasi berkelas. Jika teknik kolaborasi terus dipertahankan peneliti Indonesia, diprediksi produk riset energi yang termuat terbitan internasional akan bertambah besar.

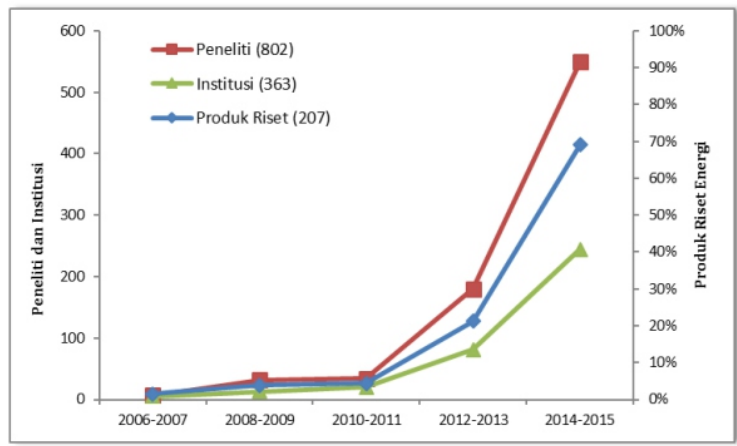

Gambar 1. Riset Konsorsium Indonesia Bidang Energi 2006-2015

Menurut tabel 1 terdapat 14 jurnal ilmiah Science Direct, telah memuat produk riset energi yang disusun melalui kolaborasi. Sedangkan dari hasil pelacakan pada mesin Scimago Journal Rank (SJR), ke-14 jurnal sudah memiliki peringkat. Meskipun dengan peringkat bervariasi, namun semua jurnal telah sahih untuk menyandang terbitan berkala ilmiah bereputasi global. Mengingat SJR merupakan wujud kesetaraan Scopus yang bisa dirujuk guna menganalisis pamor terbitan berkala ilmiah. Selain itu jurnal ilmiah umumnya terwujud dari pendekatan antar disiplin ilmu, namun berkaitan dan terfokus pada satu objek persoalan (LIPI, 2014:6). Bila dikaitkan dengan ke-14 jurnal, maka dapat diartikan bahwa riset energi yang dipimpin Indonesia telah menggali terobosan inovatif dengan berbagai cabang keilmuan.

\section{b. Konstruksi Penelitian}

Tampilan tabel 2 menunjukkan indeks kolaborasi ke dalam empat pilar menurut kepulauan nasional. Untuk rasio ilmuwan diperoleh 3.87, kemudian afiliasi sebesar 1.75, negara senilai 1.29, dan regional sebanyak 1.24. Terlihat bahwa indeks kolaborasi yang diraih pulau Sumatera, umumnya telah mengungguli rerata dari kepulauan lainnya. Desain keanggotaan riset yang sudah dijalankan 
Performa Indonesia pada Riset Konsorsium.../Himawanto

Tabel 1. Saluran Publikasi Internasional Untuk Riset Konsorsium Energi Indonesia

\begin{tabular}{|c|c|c|c|c|c|c|}
\hline Hasil Riset & Jurnal Ilmiah & SJR 2015 & \multicolumn{2}{|c|}{ Ilmuwan (R1) } & \multicolumn{2}{|c|}{ Lembaga (R2) } \\
\hline 149 & Energy Procedia & 0.378 & 566 & $(3.80)$ & 241 & $(1.62)$ \\
\hline 11 & International Journal of Hydrogen Energy & 1.330 & 62 & $(5.64)$ & 28 & $(2.55)$ \\
\hline 7 & Energy Conversion and Management & 2.156 & 27 & $(3.86)$ & 14 & $(2.00)$ \\
\hline 7 & Annals of Nuclear Energy & 1.199 & 24 & $(3.43)$ & 16 & $(2.29)$ \\
\hline 6 & Progress in Nuclear Energy & 0.924 & 28 & $(4.67)$ & 9 & $(1.50)$ \\
\hline 5 & Renewable Energy & 1.961 & 20 & $(4.00)$ & 11 & $(2.20)$ \\
\hline 4 & Energy & 2.350 & 20 & $(5.00)$ & 7 & $(1.75)$ \\
\hline 4 & Solar Energy Materials and Solar Cells & 1.996 & 14 & $(3.50)$ & 7 & $(1.75)$ \\
\hline 3 & Applied Energy & 2.998 & 9 & $(3.00)$ & 6 & $(2.00)$ \\
\hline 3 & Energy Policy & 2.436 & 7 & $(2.33)$ & 5 & $(1.67)$ \\
\hline 3 & Energy and Buildings & 2.073 & 12 & $(4.00)$ & 9 & $(3.00)$ \\
\hline 3 & International Journal of Electrical Power \& Energy Systems & 1.741 & 9 & $(3.00)$ & 6 & $(2.00)$ \\
\hline 1 & Energy Economics & 3.025 & 2 & $(2.00)$ & 2 & $(2.00)$ \\
\hline 1 & Sustainable Energy Technologies and Assessments & 1.057 & 2 & $(2.00)$ & 2 & $(2.00)$ \\
\hline
\end{tabular}

Sumber : Data primer yang diolah, 2016; R1 (Ilmuwan/Hasil Riset); R2 (Lembaga/Hasil Riset)

Tabel 2. Indeks Kolaborasi Penelitian Bidang Energi Berasas Kepulauan Nasional

\begin{tabular}{lrrrrrrrrrr}
\hline \multicolumn{1}{c}{ Kepulauan Nasional } & Riset Kooperasi & \multicolumn{2}{c}{ Peneliti (CI) } & Afiliasi (CI) & \multicolumn{2}{c}{ Negara (CI) } & \multicolumn{2}{c}{ Regional (CI) } \\
\hline Jawa & 182 & $87.92 \%$ & 710 & $(3.90)$ & 315 & $(1.73)$ & 229 & $(1.26)$ & 220 & $(1.21)$ \\
\hline Sumatera & 14 & $6.76 \%$ & 56 & $(4.00)$ & 30 & $(2.14)$ & 24 & $(1.71)$ & 22 & $(1.57)$ \\
\hline Sulawesi & 5 & $2.42 \%$ & 15 & $(3.00)$ & 9 & $(1.80)$ & 9 & $(1.80)$ & 9 & $(1.80)$ \\
\hline Kalimantan & 3 & $1.45 \%$ & 11 & $(3.67)$ & 4 & $(1.33)$ & 3 & $(1.00)$ & 3 & $(1.00)$ \\
\hline Nusa Tenggara & 3 & $1.45 \%$ & 10 & $(3.33)$ & 5 & $(1.67)$ & 3 & $(1.00)$ & 3 & $(1.00)$ \\
\hline & 207 & $100 \%$ & 802 & $(3.87)$ & 363 & $(1.75)$ & 268 & $(1.29)$ & 257 & $(1.24)$ \\
\hline
\end{tabular}

Sumber : Data primer yang diolah, 2016; C1 (Collaboration Index/Indeks Kolaborasi)



Gambar 2. Rasio Konsorsium Penelitian Topik Energi Menurut 4 Elemen

peneliti lokal haruslah membawa angin segar bagi perkembangan pengetahuan energi. Artinya peneliti harus mampu meningkatkan produktifitasnya dengan formasi yang ada. Di samping itu periset lokal harus mampu memberikan jaminan mutu terhadap produk riset yang sudah dipublikasi.. Seperti kasus di India dengan angka sitasi 1000 kali (Manisha et a1, 2014:1104). Semakin tinggi indeks kolaborasi, maka peneliti nasional harus mampu melahirkan karya riset energi berkualitas.
Gambar 2 menunjukkan formasi riset dari empat pilar didistribusikan menurut kurun waktu guna mengetahui dinamikanya. Berkaitan dengan tiga pilar selain rasio peneliti, terlihat pada era 2010-2011 ketiganya memiliki indeks kolaborasi terbaik. Rasio kerjasama yang diperlihatkan institusi, negara, dan regional tercatat di skala minimum (2.00). Dilihat dari unsur regional, bisa diartikan bahwa riset energi yang digerakan peneliti lokal telah melibatkan setidaknya satu institusi asing sebagai mitra kolaborasi. Desain riset di periode 2010-2011 juga menandakan berpredikat sebagai kolaborasi global. Jika dikaitkan dengan kapasitas di masa itu, terlihat perolehannya belum begitu agresif. Namun produktifitas setelah tahun 2010-2011 amatlah drastis, meskipun ketiga rasio kooperasi beranjak turun. Bisa jadi peneliti lokal telah menunjukkan kemandiriannya tanpa selalu bergantung pada peneliti asing. Kemandirian dimaksud yaitu peneliti mulai merancang konstruksi riset dengan mengajak anggota dari institusi domestik guna menaikkan produktifitasnya. 
Kemudian hasil gambar 3 menggambarkan arsitektur riset menurut tipe afiliasi yang terbagi ke dalam dua jenis konsorsium. Institusi perguruan tinggi terlihat unggul dibandingkan kedua jenis lainnya, baik kooperasi yang bersifat lokal maupun global. Arsitektur riset yang dirancang perguruan tinggi nasional terbukti produktif menghasilkan tulisan saintifik energi selama satu dasawarsa. Sepertinya mudah bagi tipe akademisi untuk mengajak pihak manapun sebagai rekan koalisi. Mengingat akademisi selalu dianggap sebagai pencetak sumber daya manusia kredibel dan

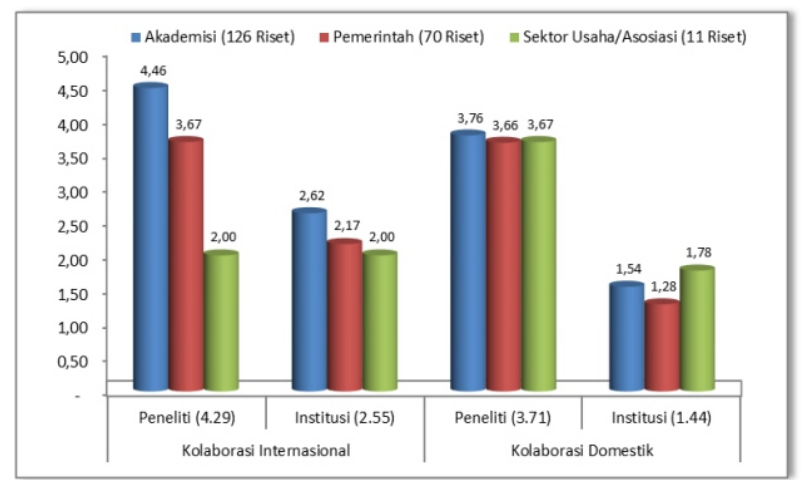

Gambar 3. Indeks Kolaborasi Menurut Jenis Produsen Karya Bidang Energi cerdas dihampir semua disiplin ilmu. Sehingga ilmuwan dapat lebih mudah menemukan gagasan dari berbagai cabang pengetahuan jika menempatkan akademisi sebagai koordinator konsorsium. Apalagi untuk mengatasi permasalahan energi sebaiknya diperlukan pendekatan antar disiplin ilmu, namun harus berkaitan.

\section{c. Kepemimpinan Nasional}

Sejak periode 2006-2015 kiprah Indonesia sebagai koordinator studi kolaborasi energi tidak lepas dari kontribusi 68 afiliasi nasionalnya. Institusi seperti PPTLM LIPI, ITB, dan UGM diketahui sebagai organisasi produktif yang sukses mengetuai studi energi berskala internasional. Kepemimpinan periset Indonesia bukan hanya bersifat lokal, namun juga bertaraf universal. Hal tersebut dapat diketahui dari keterlibatan negara asing sebagai kolega kolaborasinya. Adapun kolaborasi saintifik internasional yang telah diraih Indonesia mencapai $28.02 \%$ (58 artikel). Perlu diketahui bahwa ketiga institusi nasional tersebut pernah mengangkat harkat Indonesia sejak 2001-2011 melalui publikasinya di terbitan berkala internasional (Lakitan et al,

Tabel 3. Institusi Koordinator Domestik pada Riset Kolaborasi Bertema Energi

\begin{tabular}{|c|c|c|c|c|c|}
\hline \multirow{2}{*}{ Institusi Riset Nasional $(n=68)$} & \multicolumn{5}{|c|}{ Riset Konsorsium } \\
\hline & Jumlah & Nasional & $\%$ & Internasional & $\%$ \\
\hline Pusat Penelitian Tenaga Listrik dan Mekatronik (PPTLM) - LIPI & 22 & 22 & 10.63 & 0 & - \\
\hline Institut Teknologi Bandung (ITB) & 21 & 9 & 4.35 & 12 & 5.80 \\
\hline Universitas Gadjah Mada (UGM) & 12 & 11 & 5.31 & 1 & 0.48 \\
\hline Pusat Penelitian Kimia - LIPI & 11 & 10 & 4.83 & 1 & 0.48 \\
\hline Universitas Indonesia & 10 & 5 & 2.42 & 5 & 2.42 \\
\hline Universitas Andalas & 7 & 3 & 1.45 & 4 & 1.93 \\
\hline Universitas Padjadjaran & 6 & 6 & 2.90 & 0 & - \\
\hline UPT Balai Pengembangan Proses dan Teknologi Kimia - LIPI & 6 & 6 & 2.90 & 0 & - \\
\hline Balai Penelitian Tanaman Aneka Kacang dan Umbi & 6 & 5 & 2.42 & 1 & 0.48 \\
\hline LEMIGAS & 5 & 5 & 2.42 & 0 & - \\
\hline Universitas Merdeka Madiun & 4 & 3 & 1.45 & 1 & 0.48 \\
\hline Institut Pertanian Bogor & 4 & 3 & 1.45 & 1 & 0.48 \\
\hline Politeknik Negeri Malang & 4 & 3 & 1.45 & 1 & 0.48 \\
\hline Universitas Ma Chung & 4 & 1 & 0.48 & 3 & 1.45 \\
\hline Universitas Darma Persada & 3 & 3 & 1.45 & 0 & - \\
\hline PT. SMART Tbk. & 3 & 3 & 1.45 & 0 & - \\
\hline Universitas Muhammadiyah Malang & 3 & 3 & 1.45 & 0 & - \\
\hline Universitas Diponegoro & 3 & 3 & 1.45 & 0 & - \\
\hline Pusat Penelitian Bioteknologi - LIPI & 3 & 2 & 0.97 & 1 & 0.48 \\
\hline Universitas Jenderal Soedirman & 3 & 2 & 0.97 & 1 & 0.48 \\
\hline Universitas Hasanuddin & 3 & 1 & 0.48 & 2 & 0.97 \\
\hline Universitas Jember & 3 & 0 & - & 3 & 1.45 \\
\hline Lainnya (46 Institusi Riset Nasional) & 61 & 40 & 19.32 & 21 & 10.14 \\
\hline Jumlah & 207 & 149 & 71.98 & 58 & 28.02 \\
\hline
\end{tabular}

Sumber : Data primer yang diolah, 2016 
2012:233). Aksi ketiganya di masa tersebut ditunjukan dengan memimpin sejumlah riset konsorsium dengan merekrut institusi dalam dan luar negeri. Tentu untuk meningkatkan kepemimpinan nasional disebuah riset bertaraf global, peneliti perlu menjangkitkan strategi kreatifnya. Tujuannya agar afiliasi lokal yang kurang dominan perannya tidak selalu mengandalkan pada lembaga yang saat ini telah banyak berhasil memasarkan karya risetnya di dunia internasional.

Tabel 4 terdapat 18 propinsi domestik telah memperlihatkan kebolehannya dalam mengetuai riset kolaborasi. Dari sejumlah

Tabel 3. Institusi Koordinator Domestik pada Riset Kolaborasi Bertema Energi

\begin{tabular}{|c|c|c|c|c|c|}
\hline \multirow{2}{*}{ Institusi Riset Nasional $(n=68)$} & \multicolumn{5}{|c|}{ Riset Konsorsium } \\
\hline & Jumlah & Nasional & $\%$ & Internasional & $\%$ \\
\hline Pusat Penelitian Tenaga Listrik dan Mekatronik (PPTLM) - LIPI & 22 & 22 & 10.63 & 0 & - \\
\hline Institut Teknologi Bandung (ITB) & 21 & 9 & 4.35 & 12 & 5.80 \\
\hline Universitas Gadjah Mada (UGM) & 12 & 11 & 5.31 & 1 & 0.48 \\
\hline Pusat Penelitian Kimia - LIPI & 11 & 10 & 4.83 & 1 & 0.48 \\
\hline Universitas Indonesia & 10 & 5 & 2.42 & 5 & 2.42 \\
\hline Universitas Andalas & 7 & 3 & 1.45 & 4 & 1.93 \\
\hline Universitas Padjadjaran & 6 & 6 & 2.90 & 0 & - \\
\hline UPT Balai Pengembangan Proses dan Teknologi Kimia - LIPI & 6 & 6 & 2.90 & 0 & - \\
\hline Balai Penelitian Tanaman Aneka Kacang dan Umbi & 6 & 5 & 2.42 & 1 & 0.48 \\
\hline LEMIGAS & 5 & 5 & 2.42 & 0 & - \\
\hline Universitas Merdeka Madiun & 4 & 3 & 1.45 & 1 & 0.48 \\
\hline Institut Pertanian Bogor & 4 & 3 & 1.45 & 1 & 0.48 \\
\hline Politeknik Negeri Malang & 4 & 3 & 1.45 & 1 & 0.48 \\
\hline Universitas Ma Chung & 4 & 1 & 0.48 & 3 & 1.45 \\
\hline Universitas Darma Persada & 3 & 3 & 1.45 & 0 & - \\
\hline PT. SMART Tbk. & 3 & 3 & 1.45 & 0 & - \\
\hline Universitas Muhammadiyah Malang & 3 & 3 & 1.45 & 0 & - \\
\hline Universitas Diponegoro & 3 & 3 & 1.45 & 0 & - \\
\hline Pusat Penelitian Bioteknologi - LIPI & 3 & 2 & 0.97 & 1 & 0.48 \\
\hline Universitas Jenderal Soedirman & 3 & 2 & 0.97 & 1 & 0.48 \\
\hline Universitas Hasanuddin & 3 & 1 & 0.48 & 2 & 0.97 \\
\hline Universitas Jember & 3 & 0 & - & 3 & 1.45 \\
\hline Lainnya (46 Institusi Riset Nasional) & 61 & 40 & 19.32 & 21 & 10.14 \\
\hline Jumlah & 207 & 149 & 71.98 & 58 & 28.02 \\
\hline
\end{tabular}

Sumber : Data primer yang diolah, 2016

Tabel 4. Propinsi Nasional Penghasil Karya Kolaborasi Bidang Energi

\begin{tabular}{lcccccccc}
\hline \multicolumn{1}{c}{ Nama Propinsi } & Koaliasi Domestik & Koalisi Global & Produk Koalisi & Peneliti (IK) & Institusi (IK) \\
\hline Jawa Barat & 55 & 22 & 77 & $37.20 \%$ & 315 & $(4.09)$ & 129 & $(1.68)$ \\
\hline Jawa Timur & 21 & 11 & 32 & $15.46 \%$ & 122 & $(3.81)$ & 67 & $(2.09)$ \\
\hline Yogyakarta & 20 & 2 & 22 & $10.63 \%$ & 82 & $(3.73)$ & 29 & $(1.32)$ \\
\hline DKI Jakarta & 18 & 3 & 21 & $10.14 \%$ & 81 & $(3.86)$ & 44 & $(2.10)$ \\
\hline Banten & 16 & 4 & 20 & $9.66 \%$ & 77 & $(3.85)$ & 29 & $(1.45)$ \\
\hline Jawa Tengah & 7 & 3 & 10 & $4.83 \%$ & 33 & $(3.30)$ & 17 & $(1.70)$ \\
\hline Sumatera Barat & 3 & 4 & 7 & $3.38 \%$ & 23 & $(3.29)$ & 14 & $(2.00)$ \\
\hline Sulawesi Selatan & 1 & 3 & 4 & $1.93 \%$ & 11 & $(2.75)$ & 8 & $(2.00)$ \\
\hline Bali & 2 & 0 & 2 & $0.97 \%$ & 7 & $(3.50)$ & 3 & $(1.50)$ \\
\hline Kalimantan Barat & 2 & 0 & 2 & $0.97 \%$ & 8 & $(4.00)$ & 3 & $(1.50)$ \\
\hline Aceh & 0 & 2 & 2 & $0.97 \%$ & 14 & $(7.00)$ & 7 & $(3.50)$ \\
\hline Lampung & 0 & 2 & 2 & $0.97 \%$ & 7 & $(3.50)$ & 4 & $(2.00)$ \\
\hline Kalimantan Selatan & 1 & 0 & 1 & $0.48 \%$ & 3 & $(3.00)$ & 1 & $(1.00)$ \\
\hline Nusa Tenggara Barat & 1 & 0 & 1 & $0.48 \%$ & 3 & $(3.00)$ & 2 & $(2.00)$ \\
\hline Sulawesi Tenggara & 1 & 0 & 1 & $0.48 \%$ & 4 & $(4.00)$ & 1 & $(1.00)$ \\
\hline Sumatera Utara & 1 & 0 & 1 & $0.48 \%$ & 3 & $(3.00)$ & 1 & $(1.00)$ \\
\hline Bengkulu & 0 & 1 & 1 & $0.48 \%$ & 3 & $(3.00)$ & 2 & $(2.00)$ \\
\hline Sumatera Selatan & 0 & 1 & 1 & $0.48 \%$ & 6 & $(6.00)$ & 2 & $(2.00)$ \\
\hline Sumbr Data
\end{tabular}

Sumber : Data primer yang diolah, 2016. IK (Indeks Kolaborasi) 
propinsi, indeks kolaborasi yang terbilang fantastis di peroleh Aceh dengan angka 7.00 periset dan 3.50 institusi. Bahkan rasio tersebut diraih dengan cara kemitraan internasional.

Tentu disadari bahwa memimpin penelitian energi berskala luas, dibutuhkan kompetensi yang harus memadai atau bahkan andal. Kompetensi tersebut dimaknai bahwa periset nasional mampu mengatur setiap individu untuk meraih tujuan yang sudah direncanakan. Apalagi tingginya angka rasio tentunya memiliki persamaan akan tanggungjawab yang besar juga. Menjadi tanda tanya tentunya jika karya riset energi yang sudah dihasilkan kurang memberi dampak ilmiah bagi kemajuan pengetahuan.

\section{d. Persekutuan Ilmuwan}

Kemudian tampilan tabel 5 menayangkan kiprah 21 negara sekutu dalam riset konsorsium energi yang dipimpin Indonesia. Dengan mengesampingkan bahasan tentang sekutu domestik, terlihat bahwa Jepang menjadi negara sahabat teraktif. Nampaknya bukan hanya di Indonesia saja Jepang begitu aktif menyokong riset konsorsium. Empat jenis riset termasuk energi periode 1996-2010 di Taiwan ternyata memposisikan Jepang sebagai mitra utama (Liu et al, 2012:150). Demikian juga riset nanoteknologi di Cina yang telah menempatkan Jepang diperingkat kedua setelah Amerika Serikat (Tang et al, 2011:6). Namun kemitraan Indonesia sebaiknya tidak terbatas pada 21 negara saja. Seperti Spanyol yang telah berkolaborasi dengan 104 negara untuk kajian energinya tahun 1957-2012 (Montoya et al, 2014:176). Misalnya Cina yang berkoalisi dengan 75 negara terhadap riset energi dan bahan bakarnya sejak 1993-2012 (Chen et al, 2016:970). Selain mempererat, tentu Indonesia masih perlu menambah sekutu baru. Jika terealisasi, pengakuan masyarakat ilmiah global terhadap Indonesia akan semakin tinggi.

Terdapat 50 afiliasi riset asing yang melakukan koalisi dibawah komando peneliti nasional, yakni sekutu primer berasal dari insitusi yang bernaung di negara Jepang, Italia, serta Taiwan. Frekuensi kemunculan paling tinggi mencapai $9.01 \%$, diikuti dengan angka $7.21 \%$ dan $5.41 \%$. Dari pemetaan hasil, nampak pada tabel 6 terdapat institusi asing yang belum banyak berkoalisi dalam aksi kolaborasi ilmiah dengan lembaga nasional. Kemunculannya juga tergolong rendah yaitu sekali selama satu dekade. Padahal kolaborasi saintifik semestinya tidak cukup jika dilakukan hanya sekali. Apalagi guna mengatasi perkara energi, sepatutnya ditempuh persekutuan secara berkelanjutan. Untuk itu, menampilkan bukti

Tabel 5. Pasangan Negara Untuk Riset Konsorsium Energi Indonesia

\begin{tabular}{|c|c|c|c|c|}
\hline Negara Mitra & Regional & Benua & Kemunculan (Posisi) & $\%$ Kemunculan \\
\hline Jepang & Asia Timur & Asia & 40 & $36.04 \%$ \\
\hline Malaysia & Asia Tenggara & Asia & (2) & $11.71 \%$ \\
\hline Italia & Eropa Selatan & Eropa & (3) & $8.11 \%$ \\
\hline Taiwan & Asia Timur & Asia & $8 \quad(4)$ & $7.21 \%$ \\
\hline Australia & Asia Pasifik & Asia & $(5)$ & $5.41 \%$ \\
\hline Spanyol & Eropa Selatan & Eropa & (6) & $4.50 \%$ \\
\hline Turki & Asia Barat & Asia & 5 & $4.50 \%$ \\
\hline Belanda & Eropa Barat & Eropa & (7) & $2.70 \%$ \\
\hline Inggris & Eropa Utara & Eropa & 3 & $2.70 \%$ \\
\hline Jerman & Eropa Barat & Eropa & 3 & $2.70 \%$ \\
\hline Amerika Serikat & Amerika Utara & Amerika & $(8)$ & $1.80 \%$ \\
\hline India & Asia Selatan & Asia & 2 & $1.80 \%$ \\
\hline Polandia & Eropa Timur & Eropa & 2 & $1.80 \%$ \\
\hline Swedia & Eropa Utara & Eropa & 2 & $1.80 \%$ \\
\hline Thailand & Asia Tenggara & Asia & 2 & $1.80 \%$ \\
\hline Hongaria & Eropa Timur & Eropa & $(9)$ & $0.90 \%$ \\
\hline Kanada & Amerika Utara & Amerika & 1 & $0.90 \%$ \\
\hline Korea Selatan & Asia Timur & Asia & 1 & $0.90 \%$ \\
\hline Nigeria & Afrika Barat & Afrika & 1 & $0.90 \%$ \\
\hline Singapura & Asia Tenggara & Asia & 1 & $0.90 \%$ \\
\hline Vietnam & Asia Tenggara & Asia & 1 & $0.90 \%$ \\
\hline & Jumlah & & 111 & $100 \%$ \\
\hline
\end{tabular}

Sumber : Data primer yang diolah, 2016. 
Tabel 6. Lembaga Kemitraan Asing di Kegiatan Riset Energi Indonesia 2006-2015

\begin{tabular}{ccll}
\hline Nilai Presensi (\%) & \multicolumn{1}{c}{ Lembaga Asing } & Negara \\
\hline 10 & $(9.01)$ & Tokyo Institute of Technology & Jepang \\
\hline 8 & $(7.21)$ & ENEA Technical Unit Renewable Sources & Taiwan \\
\hline 6 & $(5.41)$ & National Taiwan University of Science and Technology & Jepang \\
\hline 6 & $(5.41)$ & Osaka University & Malaysia \\
\hline 5 & $(4.50)$ & Universiti Kebangsaan Malaysia & Spanyol \\
\hline 5 & $(4.50)$ & University of Lleida & Australia \\
\hline 5 & $(4.50)$ & University of Southern Queensland & Jepang \\
\hline 4 & $(3.60)$ & Kyushu University & Jepang \\
\hline 4 & $(3.60)$ & Toyohashi University of Technology & Jepang \\
\hline 3 & $(2.70)$ & Japan Atomic Energy Agency & Malaysia \\
\hline 3 & $(2.70)$ & Universiti Teknologi Malaysia & Inggris \\
\hline 3 & $(2.70)$ & University of Glasgow & Thailand \\
\hline 2 & $(1.80)$ & Asian Institute of Technology & Turki \\
\hline 2 & $(1.80)$ & Gazi University & India \\
\hline 2 & $(1.80)$ & Indian Institute of Technology & Malaysia \\
\hline 2 & $(1.80)$ & International Islamic University Malaysia & Polandia \\
\hline 2 & $(1.80)$ & Jagiellonian University & Jepang \\
\hline 2 & $(1.80)$ & Kyoto University & Taiwan \\
\hline 2 & $(1.80)$ & National Synchrotron Radiation Research Center & Malaysia \\
\hline 2 & $(1.80)$ & University Malaysia Pahang & Amerika Serikat \\
\hline 2 & $(1.80)$ & University of South Alabama & Jepang \\
\hline 2 & $(1.80)$ & University of Tokyo & Belanda \\
\hline 2 & $(1.80)$ & VU University Amsterdam & \\
\hline 27 & $(24.32)$ & Lainnya (27 Lembaga Asing) & \\
\hline
\end{tabular}

Sumber : Data primer yang diolah, 2016.

pengalaman dalam mengetuai riset energi dirasa penting jika peneliti nasional berkeinginan memperkuat intensitas kolaborasi dengan sekutu asing.

\section{E. KESIMPULAN}

Berdasarkan hasil pengungkapan fakta mengenai performa Indonesia pada riset konsorsium energi yang terekam jurnal ilmiah prestise ScienceDirect, dapat disimpulkan beberapa hal penting diantaranya:

a) Riset konsorsium energi yang dikoordinasikan Indonesia selama satu dekade telah menghasilkan 207 produk dengan pertumbuhan yang begitu pesat setelah periode 2010-2011. Sedangkan semua karya penelitian yang telah dicapai berdasarkan kemunculan 802 periset dan 363 afiliasi, telah berhasil dipublikasi melalui 14 jurnal ilmiah bereputasi.

b) Adapun indeks kolaborasi dari karya riset yang sudah diterbitkan sebesar 3.87 peneliti. Sedangkan rerata terhadap institusi, negara dan regional sudah mencapai indeks satu lebih. Hanya diperiode 2010-2011 arsitektur riset absolut diperoleh dengan kolaborasi internasional. Namun selama satu dekade konstruksi penelitian yang digerakan akademisi terbukti produktif meraih karya ilmiah.

c) Sementara itu kolaborasi saintifik yang dipimpin oleh 68 institusi nasional menyisihkan $28.02 \%$ riset berskala global. Menurut geografisnya, seluruh lembaga domestik bermukim di 18 propinsi dan Aceh menyandang sebagai zona yang memperoleh nisbah kolaborasi fantastis dengan angka 7.00 periset dan 3.50 institusi.

d) Selain bersifat lokal, Indonesia juga berkonsorsium dengan 21 negara dan Jepang terlihat begitu aktif mendukung aktivitas riset nasional. Dari kapabilitasnya, negara mitra telah mendelegasikan 50 lembaga risetnya untuk berkoalisi dengan peneliti domestik. 


\section{DAFTAR PUSTAKA}

Anyi, Kevin Wan Utap., A.N. Zainab, dan N.B. Anuar. 2009. Bibliometric studies on single journals : a review. Malaysian Journal of Library \& Information Science, 14 (1) : 17 55

Casado, Elias Sanz., Maria Luisa LascurainSánchez, Antonio Eleazar Serrano-Lopez, Birger Larsen dan Peter Ingwersen. 2014. "Production, consumption and research on solar energy: The Spanish and German case". Renewable Energy, 68 (Agustus) : $733-744$. d o i : 10.1016/j.renene.2014.03.013

Chen, Hua-Qi., Xiuping Wang, Li He, Ping Chen, Yuehua Wan, Lingyun Yang dan Shuian Jiang. 2016. "Chinese energy and fuels research priorities and trend: A bibliometric analysis". Renewable and Sustainable Energy Reviews, 58 (Januari) : 966-975. doi: 10.1016/j.rser.2015.12.239

Chen, Huaqi dan Yuh-Shan Ho. 2015. "Highly cited articles in biomass research: A bibliometric analysis". Renewable and Sustainable Energy Reviews, 49 (September) :12-20. doi: 10.1016/j.rser.2015.04.060

Dutt, Bharvi dan Khaiser Nikam. 2013. "Solar cell research in India: A scientometric profile". Annals of Library and Information Studies, $60(2): 115-127$

Dutt, Bharvi dan Khaiser Nikam. 2014. "Scientometrics of collaboration pattern in solar cell research in India". Annals of Library and Information Studies, 61 (1) : 65-73

Dutt, Bharvi dan Khaiser Nikam. 2015. "A scientometric overview of collaboration pattern in global solar cell research". Annals of Library and Information Studies, $62(3): 157-167$

Gazni, Ali., Cassidy R. Sugimoto dan Fereshteh Didegah. 2012. "Mapping world scientific collaboration: Authors, institutions, and countries". Journal of the American Society for Information Science and Technology, 63 (2) : 323-335. doi: 10.1002/asi.21688

Guo, Lin., Fei Xu, Zhigang Feng dan Guofan Zhang. 2016. "A bibliometric analysis of oyster research from 1991 to 2014". Aquaculture International, 24 (1) : 327-344. doi: $10.1007 / \mathrm{s} 10499-015-9928-1$
Fizzanty, Trina., Kusnandar, Dini Oktaviyanti, Wati Hermawati, Radot Manalu dan Ishelina Rosaira. 2013. "Tipologi, efektivitas dan elemen-elemen utama dalam kolaborasi riset internasional: studi kasus pada beberapa proyek riset internasional di LIPI". Warta Kebijakan Iptek \& Manajemen Litbang, 11 (2): 101-106

Hoppen, Natascha Helena Franz dan Samile Andrea de Souza Vanz. 2016. "Neurosciences in Brazil: a bibliometric study of main characteristics, collaboration and citations". Scientometrics, 1-21. doi: 10.1007/s11192-016-1919-0

Hou, Qian., Guozhu Mao, Lin Zhao, Huibin Du dan Jian Zuo. 2015. "Mapping the scientific research on life cycle assessment: a bibliometric analysis". International Journal of Life Cycle Assessment, 20 (4) : 541-555. doi: 10.1007/s11367-015-0846-2

Jiang, Hanchen., Maoshan Qiang dan Peng Lin. 2016. "A topic modeling based bibliometric exploration of hydropower research". Renewable and Sustainable Energy Reviews, 57 (Mei) : 226-237. doi: 10.1016/j.rser.2015.12.194

Karimi, Faezeh dan Rajab Khalilpour. 2015. "Evolution of carbon capture and storage research: Trends of international collaborations and knowledge maps". International Journal of Greenhouse Gas Control, 37 (Juni) : 362-376. doi: 10.1016/j.ijggc.2015.04.002

Lakitan, Benyamin., Dudi Hidayat dan Siti Herlinda. 2012. "Scientific productivity and the collaboration intensity of Indonesian universities and public R\&D institutions: Are there dependencies on collaborative R\&D with foreign institutions?". Technology in Society, 34 (3) : 227-238. doi: 10.1016/j.techsoc.2012.06.001

Liu, Hsuan-I, Bi-Chun Chang dan Kuan-Chia Chen. 2012. "Collaboration patterns of Taiwanese scientific publications in various research areas". Scientometrics, 92 (1) : 145-155. doi: 10.1007/s11192-012-0719-4

Mao, Guozhu., Hongyang Zou, Guanyi Chen, Huibin Du dan Jian Zuo. 2015. "Past, current and future of biomass energy research: A bibliometric analysis". Renewable and Sustainable Energy Reviews, 52 (Desember) : 1823-1833. doi: 10.1016/j.rser.2015.07.141 
Mao, Guozhu., Xi Liu, Huibin Du, Jian Zuo dan Linyuan Wang. 2015. "Way forward for alternative energy research: A bibliometric analysis during 1994-2013". Renewable and Sustainable Energy Reviews, 48 (Agustus ) : 276-286. doi : 10.1016/j.rser.2015.03.094

Maryono dan Sri Junandi. 2012. "Indonesian Journal of Chemistry 2007-2011: analisis kolaborasi dan institusi". Visi Pustaka, 14 (3) : 13-23

Maryono dan Sri Junandi. 2012. "Tren impact factor, produktivitas, dan kolaborasi dalam Indonesian Journal of Chemistry". IPTEKKOM, $14(2): 115-132$

Mindeli, L.E., dan V.A. Markusova. 2015. "Bibliometric studies of scientific collaboration: International trends". Automatic Documentation and Mathematical Linguistics, 49 (2) : 59-64. doi:10.3103/S0005105515020065

Montoya, Francisco G., Maria G. Montoya, Julio Gomez, Francisco Manzano-Agugliaro dan Enrique Alameda-Hernandez. 2014. "The research on energy in spain: A scientometric approach". Renewable and Sustainable Energy Reviews, 29 (Januari) : 173-183. doi: 10.1016/j.rser.2013.08.094

Nashihuddin, Wahid dan Rochani Nani Rahayu. 2013. "Aksesibilitas informasi ilmiah Science Direct Pustaka Ristek di lingkungan Ristek dan LPNK". Jurnal Pustakawan Indonesia, 12 (2) : 1-9. (http://jurnal.ipb.ac.id/index.php/jpi/articl e/view/11493/8988)

Nugroho, Andry Satrio. 2015. "Analisis ketahanan minyak di 15 negara pengimpor minyak tahun 2010". Bina Ekonomi, 19 (1): 71-89

Pattah, Sitti Husaebah. 2013. "Pemanfaatan kajian bibliometrika sebagai metode evaluasi dan kajian dalam ilmu perpustakaan dan informasi". Khizanah Al-Hikmah, 1 (1) : 4 7-57. (ht tp://journal.uin alauddin.ac.id/index.php/khizanah-alhikmah/article/view/25)

Peraturan Kepala Lembaga Ilmu Pengetahuan Indonesia Nomor 3 Tahun 2014. Pedoman Akreditasi Majalah Ilmiah. Jakarta 29 Agustus 2014

Rousseau, Ronald. 2011. "Comments on the modified collaborative coefficient". Scientometrics, 87 (1) : 171-174. doi: 10.1007/s11192-010-0300-y
Sarwar, Raheem dan Saeed-UI Hassan. 2015. "A bibliometric assessment of scientific productivity and international collaboration of the Islamic World in science and technology (S\&T) areas". Scientometrics, 105 (2) : 1059-1077. doi: 10.1007/s11192-015-1718-z

Subramanyam, K. 1983. Bibliometrics studies of research collaboration: a review. Journal of Information Science, $6: 33-38$

Surjandari, Isti., Arian Dhini, Esther Widya Impola Lumbantobing, Anita Titiani Widari, dan Irfan Prawiradinata. 2015. "Big Data Analysis of Indonesian Scholars' Publications: A Research Theme Mapping". International Journal of Technology, 6 (4) : 650-658. doi: 10.14716/ijtech.v6i4.1956

Tambunan, Kamariah. 2013. "Riset unggulan terpadu : kajian bibliometrika". Baca : Jurnal Dokumentasi dan Informasi, 34 (2) : 105-122

Tang, Li dan Philip Shapira. 2011. "China-US scientific collaboration in nanotechnology: patterns and dynamics". Scientometrics, 88 (1) : 1-16. doi: 10.1007/s11192-011-0376-Z

Terekhov, Alexander I. 2015. "R \& D on carbon nanostructures in Russia: scientometric analysis, 1990-2011". Journal of Nanoparticle Research, 17 (2) : 1-26. doi: 10.1007/s11051-015-2897-5

Wan, Terng-Jou Wan., Shu-Min Shen, Amitava Bandyopadhyay dan Chi-Min Shu. 2012. "Bibliometric analysis of carbon dioxide reduction research trends during 1999-2009". Separation and Purification Technology, 94 (19) : 87-91. doi: 10.1016/j.seppur.2011.07.022

Wang, Bing., Su-Yan Pan, Ruo-Yu Ke, Ke Wang dan Yi-Ming Wei. 2014. "An overview of climate change vulnerability: a bibliometric analysis based on Web of Science database". Natural Hazards, 74 (3) : 1649-1666. doi: 10.1007/s11069-014$1260-\mathrm{y}$

Wang, Xianwen., Shenmeng Xu, Zhi Wang, Lian Peng dan Chuanli Wang. 2013. "International scientific collaboration of China: collaborating countries, institutions and individuals". Scientometrics, 95 (3) : 885-894. doi: 10.1007/s11192-012-0877-4 
Wei, Meiyang., Wanming Wang dan Yanfeng Zhuang. 2016. "Worldwide research productivity in the field of spine surgery: a 10-year bibliometric analysis". European Spine Journal, 25 (4) : 976-982. doi: $10.1007 / \mathrm{s} 00586-016-4442-3$

Yaoyang, Xu dan Wiebke J. Boeing. 2013. "Mapping biofuel field: A bibliometric evaluation of research output". Renewable and Sustainable Energy Reviews, 28 ( D e s e mber) : $82-91$. d o i : 10.1016/j.rser.2013.07.027
Yu, Qi., Hongfang Shao, Peifeng He dan Zhiguang Duan. 2013. "World scientific collaboration in coronary heart disease research". International Journal of Cardiology, 167 (3) : 631-639. doi: 10.1016/j.ijcard.2012.09.134

Zhang, Kun., Qian Wang, Qiao-Mei Liang dan Hao Chen. 2016. "A bibliometric analysis of research on carbon tax from 1989 to 2014". Renewable and Sustainable Energy Reviews, 58 (Mei) : 297-310. doi : 10.1016/j.rser.2015.12.089 